\title{
FINANCIAL LITERACY OF THE MANAGEMENT STUDENTS - CZECH AND SLOVAK EXPERIENCE
}

\author{
Ales Kozubik \\ Dpt. of Mathematical Methods and Operations Research, Faculty of \\ Management and Informatics, University of Zilina, Zilina, Slovakia \\ CMESTE \\ JEL Category: G53
}

\begin{abstract}
Financial literacy is becoming one of the key competencies in the 21st century. In its absence, it is virtually impossible to navigate the market for financial products and services and thus ensure financial stability throughout the whole life. The author presents the results of a survey of the financial literacy of young future managers who are currently university students. Based on a questionnaire survey among full-time and part-time students, the author detects the positive impact of the practical experience of external students on their financial literacy. The author uses an innovative metric in the form of a personal finance index to assess financial literacy. In addition to overall success, this approach also makes it possible to analyze knowledge from the eight components of financial literacy. By comparing the results in individual areas, the author reveals that risk management is Achyla's heel of financial literacy. In addition to the knowledge component, the author also deals with the respondents' access to information sources. Based on these findings, the author formulates conclusions for the content of financial education. There is a need for a stronger link between the development of probabilistic thinking and the development of general numeracy with practical financial subjects. An important part of financial education is also the recognition of credible information sources.
\end{abstract}

Keywords: financial education, financial literacy, financial management, questionnaire survey, decision making,

\section{INTRODUCTION}

The beginning of the new millennium is associated with the massive dynamic development of new technologies, especially in the field of electronics and digitization. Against the background of this development, it is impossible to overlook how these technologies allow the emergence of new

The address of the author:

Aleš Kozubík

洯alesko@frcatel.fri.uniza.sk financial instruments. A characteristic feature of these tools is their growing complexity and sophistication, but also easy accessibility for everyone. It is this easy accessibility that underlines the growing importance of financial literacy. A low-literate or even financially illiterate individual will then easily drown in a sea of pitfalls of complex financial products.

The current post-COVID period confirms the importance of financial literacy. It is not easy to navigate the maze of government support programs, loans, or repayment deferrals. Their 
wrong choice can easily lead to the financial instability of an individual, his family, or company in the future, and even bankruptcy.

Also, we need to realize that people make the most long-term and vital financial decisions at a young age having insufficient experience. As an example of such decisions, we can mention the choice of a suitable way of housing financing or a suitable pension plan. It is, therefore, necessary to pay attention to financial education at all levels of the education system.

In this article, we present the results of a financial literacy survey of university students. In doing so, we focused on the students of the managerial departments of the study, as in their case the importance of financial literacy is amplified by the fact that in the future, they will decide not only on their private financial situation but also on the financial stability and well-being of companies and thus the economy as the whole. To assess the impact of practical experience, we surveyed students of both forms of study: full-time and parttime. Based on the results of the research, we will conclude about improving the level of financial education.

\section{LITERATURE SURVEY}

Several authors approach the content of the concept of financial literacy differently. However, it is generally perceived as the ability to understand finance. Let us document the variability of the understanding of financial literacy on at least a few examples. Kim gives a relatively simple definition of financial literacy: „Financial literacy is the basic knowledge that people need to survive in a modern society." (Kim, 2001). (Mandell, 2007) characterizes financial literacy in a little more detail: "It is the ability to evaluate the new and complex financial instruments and make informed judgments about both: choices of instruments and extent of use that would be in their own best longrun interests". Some approaches seek to define financial literacy as a set of competencies that an individual should have to make informed financial decisions. We can meet with this, for example, at work (Giesler \& Veresiu, 2014). They define financial literacy as:" The ability to understand how money works in the world: how someone manages to earn or make it, how that person manages it, how he/she invests it (turn it into more) and how that person donates it to help others." Remund says that financial literacy "is a measure of the degree to which one understands key financial concepts and possesses the ability and confidence to manage personal finances through appropriate short-term decision-making and sound, long-range financial planning, while mindful of life events and changing economic conditions" (Remund, 2010). In this research, we adopt the definition of the financial literate person by (Kozubíková, 2015): "A person who uses his ability to make a qualified judgment based on the knowledge, skills and experience gained thus enabling him to smooth financial security throughout life".

The measurement of financial literacy is usually based on a questionnaire survey. It is not easy to compile a suitable questionnaire, the results of which could be easily transformed into financial literacy metrics. Lusardi and Mitchell characterized the basic principles in (Lusardi \& Mitchell, 2014). These principles are simplicity, relevance, brevity, and the capacity to differentiate. Simplicity is a requirement that questions should examine knowledge of the basic elements of financial decision making. Relevance reflects the requirement that issues be focused on elements of financial decision-making throughout life. Brevity takes into account several questions, which must not be too many, which would prevent wider acceptance of the survey. Finally, the capacity to differentiate represents the requirement that questions be conceived in a way that allows financial knowledge to be differentiated across people. How Lusardi recalled in her conference keynote: "One must assess not only what people know but also what they need to know ad then evaluate the gap between those things." (Lusardi, 2019).

Other authors highlight the significant impact that financial literacy has on the correctness of decision-making and see it as a prerequisite for good financial decisions in personal finance. A strong positive relationship between financial literacy and wealth of households is reported in (van Rooij, Lusardi, \& Alessie, 2012): "Our findings provide evidence of a strong positive association between financial literacy and net worth, even after controlling for many determinants of wealth." Furthermore, this work found that "Financial knowledge increases the likelihood of investing in the stock market, and [is] positively related to 
retirement planning, and the development of a savings plan." It may facilitate individuals' accumulation of wealth.

Several international studies confirm the positive impact of financial education on the growth of financial literacy. For example, (Fornero \& Monticone, 2011) confirmed that the most important factor influencing the differences in financial literacy is the level of attained education. Similarly, (Lusardi \& Mitchell, 2007) state "Worldwide financial education has become an important tool to surmount the growing complexity of financial decisions, especially in the life of the last generation". The positive impact of financial education on the level of financial literacy was also confirmed by a study. (Kozubíková Z. , 2017). Moreover, it has been detected that "An important factor influencing the progress in financial literacy during education is the importance that the respondents attribute to the financial literacy."

\section{METHODS}

Data for the present research was collected using a questionnaire survey method at two universities located in the Slovak Republic and, in the Czech Republic. The research focused on the management students. As a metric for financial literacy measuring we applied an innovative measure introduced in (Lusardi, Yakoboski, \& Oggero, 2017) as a personal finance index (shortly P-Fin index). They designed this P-Fin index to completely cover the eight areas of financial literacy that an individual commonly encounters in managing personal or corporate finances. Thematically, we can characterize these areas as:

- earnings, determinants of wages and income,

- consuming, budgeting and spending,

- saving, comprehension the accumulation factors,

- investing, understanding the types and risks of investments,

- borrowing and debt management,

- risk management, comprehension the uncertain outcomes,

- insurance and the understanding of coverages,

- accessing and working with information sources.
The questionnaire itself we designed to collect the personality characteristics of the respondents, such as age, gender, achieved education, etc. Within these personal characteristics, we also asked for self-assessment of the extent to which respondents feel financially literate, for the importance they attribute to financial literacy, and about the information sources they use. Participants have assigned the importance and self-assessment on the scale from 0 up to 10 , the information sources they selected from more given alternatives.

The second part of the questionnaire presented problems concerning daily financial decision making. The problems were constructed in the form of multi-choice answer options with only one correct answer and one "I do not know" option.

We have distributed the questionnaire among 540 respondents. Because some questionnaire was completed maliciously (more than one half of the "I do not know" answers), we have to clean the sample. So we obtained 449 answer sheets, which still represent a relatively high response level of approximately $83 \%$. The obtained sample contained 145 respondents of the part-time form of study and 304 respondents of full-time study what corresponds to the real ratio of these two forms of study. The proportion of women was 187 against 262 men. This small disparity is caused by the fact that one faculty is part of the technical university where men prevail.

In all cases we got sufficient subsamples to apply methods of statistical hypotheses testing. All necessary computation and graphical outputs were performed in the specialized statistical environment $\mathrm{R}$.

\section{RESULTS}

At first, let us mention some socio-demographic data we have obtained from the questionnaire survey. How mentioned above due to the presence of faculty concerned also in informatics in the research, here is some disparity in the gender structure of the sample. Our sample contained $42.6 \%$ women and $57.4 \%$ men. Because we focused on university students, the sample significantly prevails the age group of young people in the age from 18 to 25 years. This age category covers approximately three-quarters of the whole sample. There are relatively uniformly 
represented the inhabitants of rural settlements, small towns, and large agglomerations in shares of $34 \%, 36 \%$, and $30 \%$ respectively.

The survey focused on two personality characteristics, namely the importance that respondents attach to financial literacy and the self-assessment of their competencies in this area. The histograms of the responses are presented in Figures 1 and 2. Figure 1 shows the distribution of the numbers of evaluations of the importance of financial literacy on a scale from 0 to 10 , where a higher value also represents a higher level of importance. The fact that a substantial part of the respondents attributes high values to the importance of financial literacy and the share of those who reached the values from

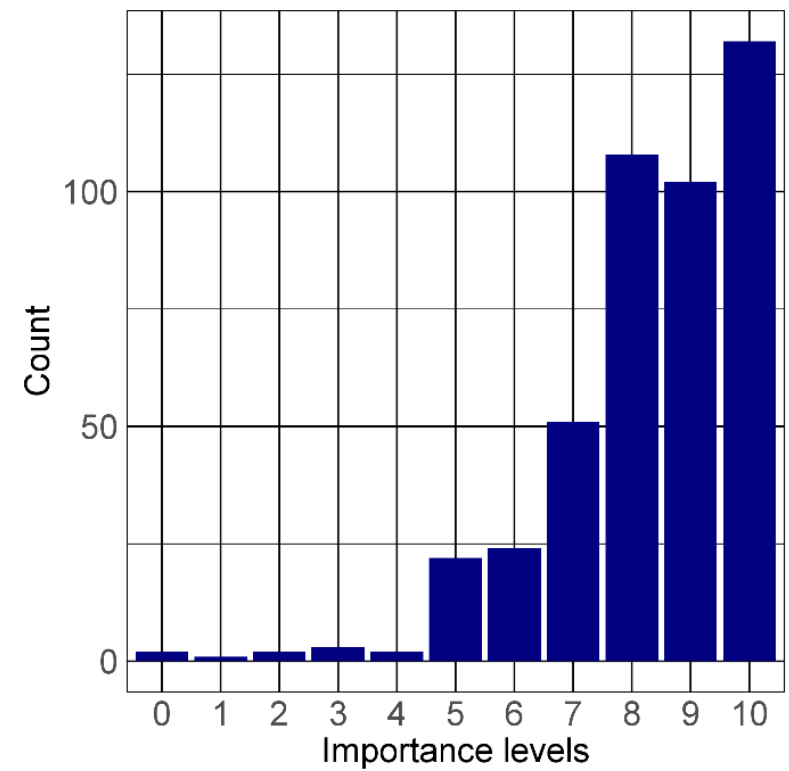

Figure 1 Histogram of the responses on the importance levels of financial literacy. Source: Own elaboration.

The construction of the P-Fin index allows two approaches to evaluating the knowledge part of the questionnaire. The first option is to express the P-Fin index in the form of an aggregate value, which indicates the percentage of correct answers. This approach was also applied in this survey when assessing the overall level of financial literacy and comparing full-time and parttime students. The second alternative is the representation of the P-Fin index in the form of an ordered 8-tuple, where each component represents the percentage success of answers in individual areas of the structure of financial the lower half of the scale is negligible can be described as favorable. Also important is the fact that the mode of division is achieved at the highest level of importance.

Figure 2 then illustrates how respondents assess their level of financial literacy. The evaluation was again performed on a scale from 0 to 10 , with higher values indicating a higher level of knowledge. Here we can notice that the maximum number of responses has shifted towards average and slightly above average responses in the range of $5-8$. Thus, there is a certain element of selfcriticism in combination with an appropriate dose of self-confidence. The numbers of overconfident as well as underestimating participants are negligible.

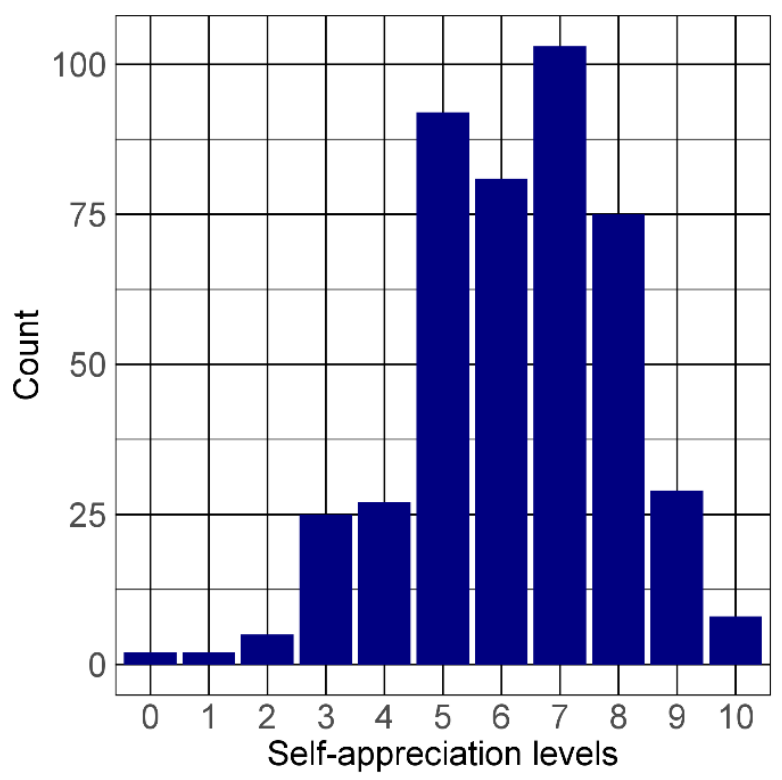

Figure 2 Histogram of the responses to the respondents' self-assessment of their financial literacy. Source: Own elaboration.

literacy. Such an approach has been used to detect weaknesses in financial literacy.

The portions of the correct answers, incorrect answers, and "I do not know" answers are illustrated graphically in Figure 3 . It is clear from the graph that incorrect answers predominate over "I do not know" answers in all items. This can be explained by the tendency of students to try to guess the correct answer instead of admitting ignorance. If we separate the results of full-time and external students, as illustrated in Table 1, we see that the number of "I do not know" answers for 

MEST Journal Vol. 9 No. 1 pp. 75-83

external students decreases, but at the same time, it increases the share of correct answers.

To get a more detailed idea of the success of the answers of full-time and part-time students, let's look at the descriptive statistics, which are summarized in Table 2 . The results show that allimportant quantiles of overall success, as well as the mean value, are shifted towards higher values in external students. This leads us to the conclusion that external students, equipped with a certain amount of practical experience, achieve a better result. This assumption can also be verified by a statistical test of the hypothesis of the equality of average successes against the one-sided alternative that the average success rate of external students is higher. As we can see from Table 3, this test allows this hypothesis to be rejected at an extremely high confidence level (The p-value is approx.. 10-15).

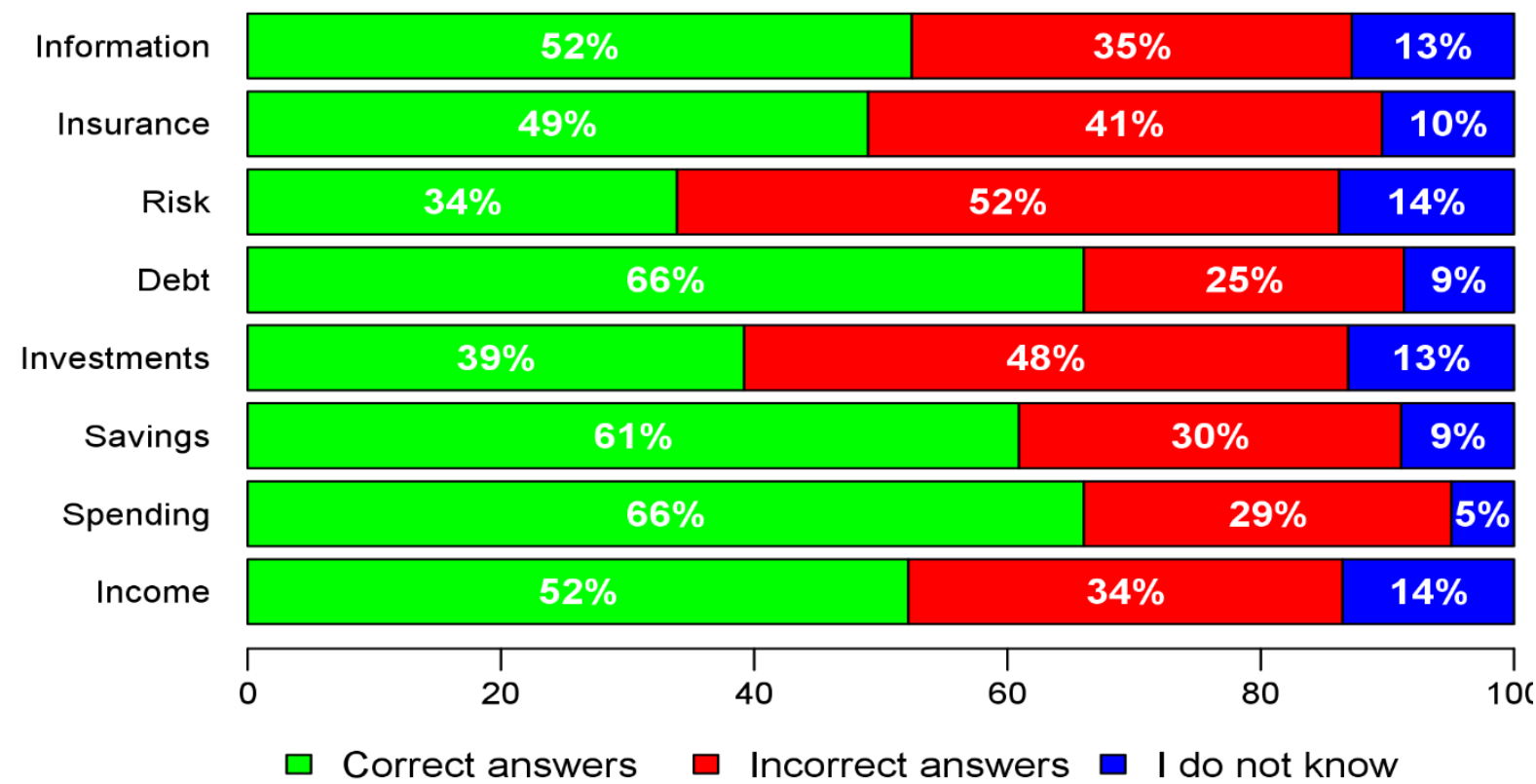

Figure 3 Shares of individual types of answers according to the components of the P-Fin index.

Source: own elaboration.

Table 1 Comparing the shares of individual types of answers according to the components of the PFin index in full-time and part-time forms of study. Source: own elaboration.

\begin{tabular}{|l|c|c|c|c|c|c|}
\hline \multirow{2}{*}{ Area } & \multicolumn{3}{|c|}{ Full-time students } & \multicolumn{3}{c|}{ Part-time student } \\
\cline { 2 - 7 } & Correct & Incorrect & $\begin{array}{l}\text { I do not } \\
\text { know }\end{array}$ & Correct & Incorrect & $\begin{array}{l}\text { I do not } \\
\text { know }\end{array}$ \\
\hline $\begin{array}{l}\text { Information } \\
\text { sources }\end{array}$ & $50 \%$ & $36 \%$ & $14 \%$ & $59 \%$ & $32 \%$ & $9 \%$ \\
\hline Insurance & $42 \%$ & $46 \%$ & $12 \%$ & $64 \%$ & $29 \%$ & $7 \%$ \\
\hline Risk & $31 \%$ & $52 \%$ & $17 \%$ & $40 \%$ & $53 \%$ & $7 \%$ \\
\hline Debt & $63 \%$ & $26 \%$ & $11 \%$ & $72 \%$ & $23 \%$ & $5 \%$ \\
\hline Investments & $35 \%$ & $48 \%$ & $17 \%$ & $48 \%$ & $48 \%$ & $4 \%$ \\
\hline Savings & $59 \%$ & $30 \%$ & $11 \%$ & $65 \%$ & $31 \%$ & $4 \%$ \\
\hline Spending & $63 \%$ & $30 \%$ & $7 \%$ & $72 \%$ & $26 \%$ & $2 \%$ \\
\hline Income & $45 \%$ & $39 \%$ & $16 \%$ & $67 \%$ & $24 \%$ & $9 \%$ \\
\hline
\end{tabular}


Kozubik, A. Financial literacy of the management students

MEST Journal Vol. 9 No. 1 pp. 75-83

Table 2. Descriptive statistics of the P-Fin scores for the whole sample and separately for full-time and part-time students Source: Own elaboration

\begin{tabular}{|l|c|c|c|c|c|c|}
\hline \multicolumn{1}{|c|}{ Group } & Min. & 1-st Quartile & Median & Mean & 3-rd Quartile & Max \\
\hline Whole & 0.10 & 0.43 & 0.53 & 0.52 & 0.60 & 0.93 \\
\hline Full-time & 0.10 & 0.40 & 0.50 & 0.48 & 0.57 & 0.90 \\
\hline Part-time & 0.17 & 0.53 & 0.60 & 0.61 & 0.73 & 0.93 \\
\hline
\end{tabular}

Table 3. Results of the two-sample Welch's t-test for the means of P-Fins scores of the full-time and part-time students. Source: Own elaboration

\begin{tabular}{|c|c|c|c|}
\hline & Mean & t-statistics & $\boldsymbol{p}$-value \\
\cline { 1 - 2 } Full-time & $48.4 \%$ & -8.4789 & $1.15 \cdot 10^{-15}$ \\
\hline Part-time & $60.9 \%$ & & \\
\hline
\end{tabular}

The more extensive Table 4 summarizes the results of tests of average success according to the individual components of financial literacy. As we can see from the table, for all components of the P-Fin index we can reject the null hypothesis of equality of pre-success. Also, by comparing $p$ values, we see that it is always at a high confidence level. It almost always exceeds the $99 \%$ level. The only exception is the case of savings management, but even here it is higher than $98 \%$.
With this decomposition of the P-Fin index into its eight components, we cannot overlook a certain drop in results in two areas. They are an understanding of risk and investment. Given that investments are always associated with a certain amount of risk, the common decline in these two areas is not accidental. The fact that these two areas are a weakness in both groups of students is well observable when displaying the resulting scores in the form of a radar graph. These are illustrated in Figures 4 and 5.

Table 4. Results of the two-sample Welch's t-test for the means of single P-Fin components scores of the full-time and part-time students. Source: Own elaboration

\begin{tabular}{|c|c|c|c|c|}
\hline Area & Form & Mean & t-statistics & p-value \\
\hline \multirow{2}{*}{ Earnings } & Full-time & $45.31 \%$ & \multirow{2}{*}{-8.6966} & \multirow{2}{*}{$2.2 \cdot 10^{-16}$} \\
\hline & Part-time & $66.55 \%$ & & \\
\hline \multirow{2}{*}{ Spending } & Full-time & $63.24 \%$ & \multirow{2}{*}{-4.0364} & \multirow{2}{*}{$3.45 \cdot 10^{-5}$} \\
\hline & Part-time & $71.90 \%$ & & \\
\hline \multirow{2}{*}{ Savings } & Full-time & $58.96 \%$ & \multirow{2}{*}{-2.1036} & \multirow{2}{*}{0.01813} \\
\hline & Part-time & $65.00 \%$ & & \\
\hline \multirow{2}{*}{ Investments } & Full-time & $35.20 \%$ & \multirow{2}{*}{-4.6121} & \multirow{2}{*}{$3.078 \cdot 10^{-6}$} \\
\hline & Part-time & $47.59 \%$ & & \\
\hline \multirow{2}{*}{$\begin{array}{l}\text { Debt } \\
\text { management }\end{array}$} & Full-time & $62.99 \%$ & \multirow{2}{*}{-3.6644} & \multirow{2}{*}{0.00015} \\
\hline & Part-time & $72.41 \%$ & & \\
\hline \multirow{2}{*}{ Insurance } & Full-time & $41.94 \%$ & \multirow{2}{*}{-8.9765} & \multirow{2}{*}{$2.2 \cdot 10^{-16}$} \\
\hline & Part-time & $63.79 \%$ & & \\
\hline \multirow{2}{*}{$\begin{array}{l}\text { Risk } \\
\text { comprehension }\end{array}$} & Full-time & $30.92 \%$ & \multirow{2}{*}{-3.6489} & \multirow{2}{*}{0.000161} \\
\hline & Part-time & $40.17 \%$ & & \\
\hline \multirow{2}{*}{$\begin{array}{l}\text { Information } \\
\text { sources }\end{array}$} & Full-time & $49.51 \%$ & \multirow{2}{*}{-2.3689} & \multirow{2}{*}{0.009273} \\
\hline & Part-time & $58.62 \%$ & & \\
\hline
\end{tabular}


At the same time, the significant drop in knowledge in the field of understanding and risk management is by no means unique. This result corresponds with many international surveys. The results across 15 countries are summarized in the

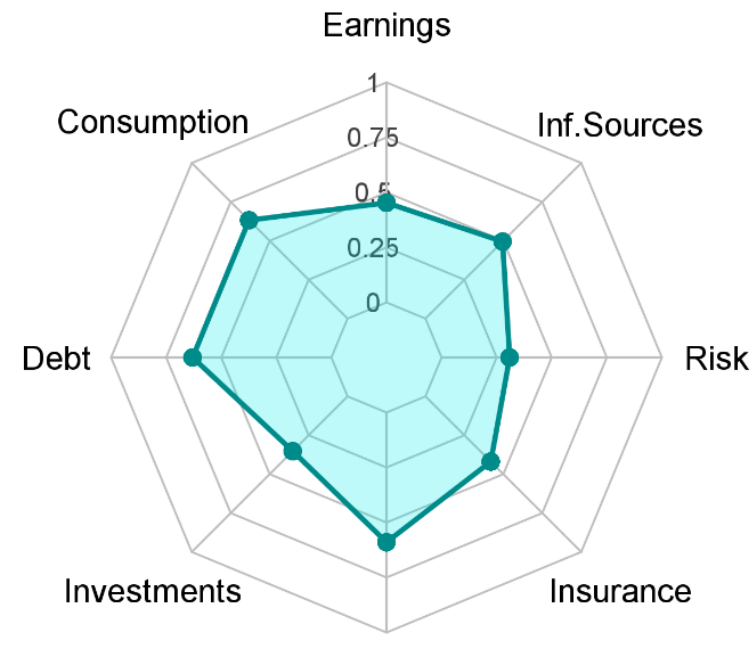

Savings

Figure 4 Radar graph of average scores of fulltime students by single components of the P-Fin index. Source: Own elaboration.

As part of the survey, we were also interested in the information resources that students use. The results are clearly illustrated by the bar chart in Figure 6 . In this context, it should be noted that respondents could choose several information sources. Therefore, after adding up all the values,

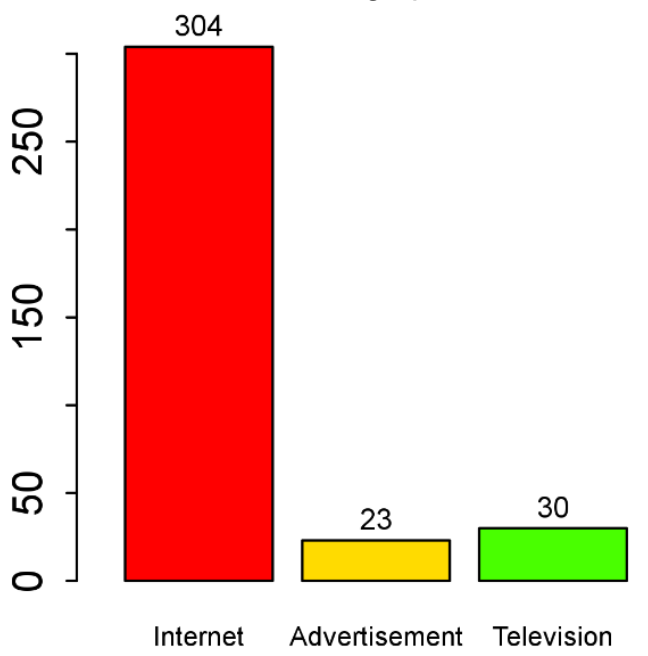

work (Lusardi) in Table 2. Except for three countries (France, Sweden, and Finland), there is more than a 10 percent drop in success in risk management. Thus, it turns out that this area is generally the weakest place in financial literacy.

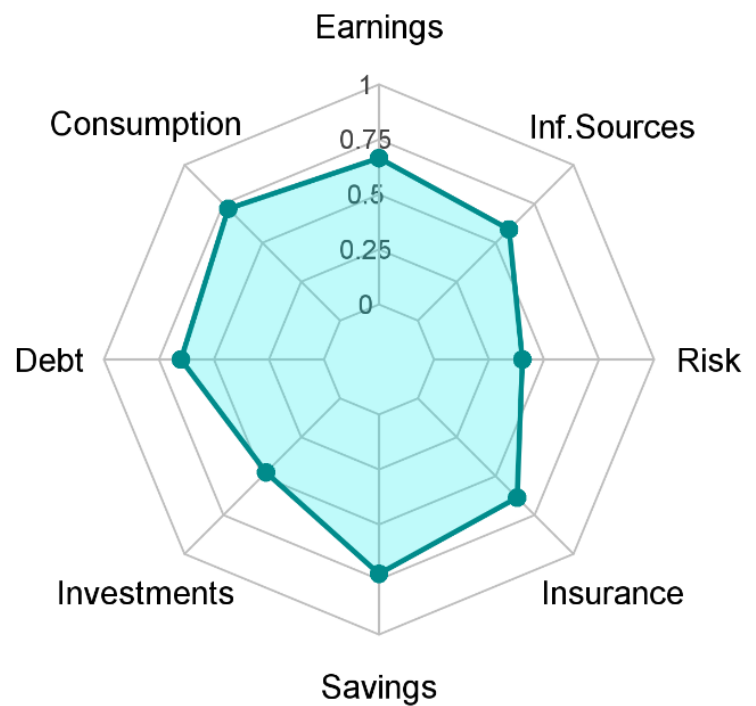

Figure 5 Radar graph of average scores of parttime students by single components of the P-Fin index. Source: Own elaboration.

we get a sum higher than the number of respondents. It turned out that the Internet as the information source significantly dominates among the answers without further specification of sites or services.

Figure 6 Bar plot of the number of responses on the use of information sources. Source: Own elaboration.

Such dominance of the Internet as an information trend of shifting attention to online tools. This is an source is, on the one hand, evidence of the current important reference for information providers who 
insist on more conservative forms. On the other hand, it is also a signal of a certain danger arising from the non-recognition of relevant information. For example, in combination with the relatively high share of friends as an information source, it is possible to conclude that it can also be a social network. There may be legitimate concerns about the reliability of the information obtained in this way. It can also be the result of marketing activities on the Internet. Also, obtaining information and advice directly from banks is often an effort to acquire a new client rather than the result of objective information. Thus, it turns out that when strengthening financial literacy, it is also necessary to address the issues of access to information resources.

\section{CONCLUSIONS}

The results obtained in the statistical analysis allow us to draw several conclusions with an impact on financial education. An important result is that it has been confirmed that external students with some practical experience achieve better results. Although practical experience cannot be fully replaced, it is at least possible to get closer. This means that in financial education, particular attention needs to be paid to decision-making and the analysis of the impact of this decision. Thus, from "What is it" education and a theoretical description of individual financial instruments, it is necessary to move to solve issues such as "How to use it", "How does it behave", and "What happens if". Addressing such outcome issues in the form of a financial decision and analysis of its impact may at least partially compensate for the lack of experience.

A significant finding is the large knowledge gap in issues of risk management and financial operations related to risk elements. This is because a proper assessment of risks and their impacts is often associated with advanced probabilistic thinking and numeracy in general. Therefore, if we want to improve the level of financial literacy in this area, it is also necessary to strengthen probability education. However, a closer link between financial subjects and mathematical background is necessary. This requires closer cooperation of teachers of both disciplines with an orientation towards solving tasks with more practical assignments. Without this approach, unfortunately, today's student, who is looking for a ready-made answer, is not even aware of the above connections and therefore cannot even use them.

A survey of the use of information sources showed that this issue cannot be circumvented in financial education either. If the Internet is the main source of information for students, it is also necessary to draw their attention to how to recognize relevant information in the field of information. They need to be taught how to verify the information in a multi-source way and not rely on the first link offered by search services. In this context, they should also be reminded that the role of marketing is not to objectively inform but to influence.

\section{WORKS CITED}

Fornero, E., \& Monticone, C. (2011). Financial literacy and pension plan participation in Italy. Journal of Pension Economics \& Finance, 10(4), 547-564. doi:10.1017/S1474747211000473

Giesler, M., \& Veresiu, E. (2014). Creating the Responsible Consumer: Moralistic Governance Regimes and Consumer Subjectivity. Journal of Consumer Research, 41(3), 840-857. doi:10.1086/677842

Kim, J. (2001). Financial knowledge and subjective and objective financial wellbeing. Consumer Interests Annual, 47, 1-3.

Kozubíková, Z. (2015). Financial Literacy as an Important Objective of Education in Economics. In P. Slavíčková (Ed.), Proceedings of the Conference: Knowledge for market use 2015: women in business in the past and present (s. 429 - 439). Olomouc: Societas Scientiarum Olomucensis II.

Kozubíková, Z. (2017). Analysis of the Impact of Economic Education on the Level of Financial Literacy. In P. Slavíčková (Ed.), International Scientific Conference Proceedings: Knowledge for Market Use: People in Economics - Decisions, Behavior and Normative Models (s. 922-931). Olomouc: Palacký University, Olomouc, 2017. 
Lusardi, A. (2019). Financial literacy and the need for financial education: evidence and implications. Swiss Journal of Economics and Statistics, 155(1). doi:https://doi.org/10.1186/s41937-0190027-5

Lusardi, A., \& Mitchell, O. (2007). Baby Boomer Retirement Security: The Role of Planning, Financial Literacy, and Housing Wealth. Journal of Monetary Economics, 54(1), 205 - 240.

Lusardi, A., \& Mitchell, O. (2014). The Economic Importance of Financial Literacy. Journal of Economic Literature, 52(1), 5-44.

Lusardi, A., Yakoboski, P. J., \& Oggero, N. (2017). The TIAA Institute-GFLEC Personal Finance Index: A New Measure of Financial Literacy. New York: TIAA Institute.

Mandell, J. (2007). Financial literacy of high school students. In J. J. Xiao (Ed.), Handbook of Consumer Finance Research (s. 163-183). New York: Springer.

Remund, D. L. (2010). Financial literacy explicated: The case for a clearer definition in an increasingly complex economy. Journal of Consumer Affairs, 44(2), 276 - 295. doi:10.1111/j.17456606.2010.01169.x

van Rooij, M. C., Lusardi, A., \& Alessie, R. J. (2012). Financial Literacy, Retirement Planning, and Household Wealth. The Economic Journal, 122(560), 449-478. doi:10.1111/j.14680297.2012.02501.x

Received for publication:

Revision received:

Accepted for publication:
17.08.2020

22.09.2020

30.12 .2020

\section{How to cite this article?}

Style - APA Sixth Edition:

Kozubik, A. (2021, January 15). Financial literacy of the management students - Czech and Slovak experience. (Z. Cekerevac, Ed.) MEST Journal, 9(1), 75-83. doi:10.12709/mest.09.09.01.10

Style - Chicago Sixteenth Edition:

Kozubik, Ales. 2021. "Financial literacy of the management students - Czech and Slovak experience." Edited by Zoran Cekerevac. MEST Journal (MESTE) 9 (1): 75-83. doi:10.12709/mest.09.09.01.10.

Style - GOST Name Sort:

Kozubik Ales Financial literacy of the management students - Czech and Slovak experience [Journal] // MEST Journal / ed. Cekerevac Zoran. - Belgrade - Toronto : MESTE, January 15, 2021. - 1 : Vol. 9. pp. 75-83.

Style - Harvard Anglia:

Kozubik, A., 2021. Financial literacy of the management students - Czech and Slovak experience. MEST Journal, 15 January, 9(1), pp. 75-83.

Style - ISO 690 Numerical Reference:

Financial literacy of the management students - Czech and Slovak experience. Kozubik, Ales. [ed.] Zoran Cekerevac. 1, Belgrade - Toronto : MESTE, January 15, 2021, MEST Journal, Vol. 9, pp. 75-83. 